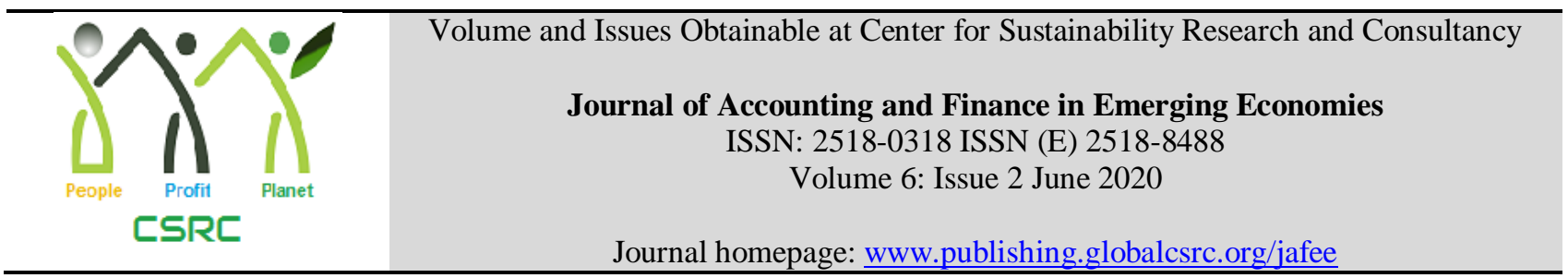

\title{
Effect of Leadership Styles on Organizational Citizenship Behavior and Employee Turnover Intention
}

\author{
${ }^{1}$ Sajid Masood, ${ }^{2}$ Ghazal Khalid Siddiqui, ${ }^{3}$ Huma Lodhi, ${ }^{4}$ Shaista Shahbaz \\ ${ }^{1}$ Assistant Professor, University of Management \& Technology, Lahore, Pakistan, \\ sajid@umt.edu.pk \\ ${ }^{2 \& 3}$ Assistant Professor University of Education Lahore, Pakistan, \\ ghazalkhalid@ue.edu.pk \\ huma.lodhi@gmail.com \\ ${ }^{4}$ Lahore College Women University Pakistan, \\ Shaistaejaz25@gmail.com
}

\section{ARTICLE DETAILS \\ History \\ Revised format: May 2020 \\ Available Online: June 2020 \\ Keywords \\ Leadership, Styles, Turnover \\ Intention, Pakistan, organizational citizenship \\ behavior, Employee}

JEL Classification

M1, M14

\begin{abstract}
The study is aimed at finding the effect of leadership styles on organizational citizenship behavior and employees' turnover intentions. A descriptive survey research strategy was adopted over a sample of 240 respondents selected conveniently from eight universities of Pakistan. Multifactor Leadership Scale developed by the Williams and Anderson (1991) was used for data collection. Turnover Intention Scale developed by Roodt (2004) was used to determine employee turnover intention. Descriptive statistics along with ANOVA were used to analyze the data. The research indicated that transformational and transactional style of leadership have a positive relationship with organizational citizenship behavior whereas, laissez faire style has a negative relation with organizational citizenship behavior and positively related with employee turnover intention. Transformational and transactional style of leadership had an insignificant relation with employee turnover intention.
\end{abstract}

\section{OPEN ACCESS}

(C) 2020 The authors, under a Creative Commons

Attribution-NonCommercial 4.0

Corresponding author's email address: sajid@umt.edu.pk

Recommended citation: Masood, S., Siddiqui, G. K., Lodhi, H., and Shahbaz, S. (2020). Effect of Leadership Styles on Organizational Citizenship Behavior and Employee Turnover Intention. Journal of Accounting and Finance in Emerging Economies, 6(2), 487-495

\section{Introduction}

It would not be wrong if we say that leaders have shaped the world as we know it today. From the days of tribal to post-knowledge era of humanity leadership it has remained center piece of human progress. There has been a focus on public role of leaders during $21^{\text {st }}$ century. The birth of corporations and large organizations witnessed a new type of leadership which subsequently gave rise to modern day leadership research studying intricate and multifaceted dynamics of relationships between leader and followers and 
their effects on various aspects of job and environment inside and outside organizations. Theories of leadership started to emerge as early as 1910 and continue to develop as technological and social changes proceed. Over the decades new challenges are giving birth to modern theories of leadership like distributed and servant leaderships and particularly in current era of pandemic the role evolved to digital leadership. Leadership was defined in that much ways in the literature as much are its proponents.

Leadership is not a recent phenomenon, however, a significant increase in studies on leadership styles were seen after emergence of leadership model by Avolio \& Bass in 2004 (Jensen et al., 2019). These leadership styles are associated with increased efficiency of employees thus result in a tremendous benefit in the form of outcomes or productivity (Kim \& Beehr, 2017). Leadership styles have been identified not only to enhance performance of the employees but their satisfaction as well in most of the settings (Teoman, \& Ulengin, 2018).

Literature about leadership identify three of such styles: Transactional, transformational and laissez faire. Transactional leaders explicitly clear expectations related to tasks, monitor the employees and award consequences (reward or punishment) accordingly. They works by monitoring the performance and rewarding them for the desired outcomes (Hassan, 2013; Popli \& Rizvi, 2016). Such leaders boost the morale of the employees as they are getting instant feedback followed by the consequences (Teoman, \& Ulengin, 2018). However, insignificant effect of transactional leadership on performance of employees was also reported in research which could have been implications for citizenship behaviors and turnover (Baig et al., 2019). Transformational leadership (TransfLead) works in a unique way, it transforms the employees from self-interest to benefits for the organization (Campbell, 2017; Jensen \& Bro, 2018). Such leaders not only create a will among the employees to focus and prioritize goals of the organization but also help the employees to develop requisite skills to successfully execute the task (Pasha et al., 2017; Bass \& Avolio, 2001. Transformational leaders trigger sacrificing self-interest among the followers and thus enhancing their loyalty with the organization and thus associated positively with organizational citizenship behaviors (Goncu, Aycan, \& Johnson, 2014). LaisfLead style is mostly equated with "non leadership style" as this type of leaders let the things move by their own or by the choices of the employees and thus usually avoid taking part in decision making and monitoring the progress (Luthan et al., 2007). Most of the research studies are challenging prospective researchers to investigate antecedents, practices and consequences of this style independently (Curtis, 2018). This style is usually negatively associated with performance of the employees thus triggering unsatisfaction and turnover (Judge \& Piccolo, 2014).

Organizational Citizenship Behavior (OCB) is voluntary individual behavior unrecognized by reward system contribute in organizational effective functioning (Organ, 1988). Organ (1988) identified three components of OCB 1) discretionary behavior 2) no recognition by reward system 3) in the long run behavior promotes organizational effectiveness. Schnake (1991) describes OCBs as "functional, extrarole, prosocial behaviors, directed at individuals, groups, and/or an organization". In last two decades many terms have been used to connote OCB like prosocial organizational behavior, extra role behavior, etc (George \& Brief, 1992). Modern literature on OCB identifies its seven components (Podsakoff, MacKenzie, Paine, \& Bachrach, 2000). OCB has been investigated by researchers since it was found to be beneficial for various organizational outcomes. Chen (2005) argues OCB has an impact on employee turnover.

Turnover remains a prime concern of organizational research despite receiving enormous attention from researchers. Holtom, Mitchell, and Lee, (2008) have identified that even though more than 1500 academic publications had tried to explain turnover but still it remains a vibrant area of research as turnover is costly in both time and money. Turnover has two types, voluntary and involuntary. Voluntary turnover has turnover intent as its antecedent. It is the thought process before actual turnover in which employee plans to leave and is the biggest cause of turnover (Kiyak, Namazi \& Kahana,1997). Cotton and Tuttle (1986) tried to explain turnover with three correlates namely external, work related, 
and personal. And further classify work related correlates into salary, job accomplishment, enjoyment with work, supervisors, co-workers and promotional opportunities. Research shows satisfaction with job and commitment with organizational are strong predictors of employee turnover intent (Karsh, Booske \& Sainfort, 2005; Guimaraes \& Igbaria, 1992). This study aims to confirm if satisfaction with head and organizational commitment has an impact on employee turnover intent and its relationship with OCB along with different leadership styles.

\section{Methodology}

This was a quantitative study employed survey as a design. The population was comprised of universities of the Punjab, Pakistan. A total of 300 questionnaires were send to the teachers; one hundred and forty-four were received back. Multifactor Leadership Questioner (MLQ), OCB measure by Somech \& Drach-Zahavy (2004) and TIS-6 was used to measure turnover intention. Sixteen (16) questions were related to leadership styles of immediate supervisor and 10 items related to OCB were further classified as Organizational Citizenship Behavior Individual (OCBI) and Organizational Citizenship Behavior Organizational (OCBO), each head containing 5 items whereas, TIS-6 has six items.

\subsection{Validity and reliability of MLQ (Form 5-X Short)}

The MLQ ( Form 5x-Short) is frequently used tool which has shown to be a valid and reliable (Howell \& Hall-Marenda, 1999; Kirkbride, 2006; Ozaralli, 2003). Avolio \& Bass (2004) found Cronbach's alpha of .64 to .92 for MLQ (Form 5X) for 36 items.

\subsection{Organizational Citizen Behavior (OCB)Measure}

In order to determine OCB, this study used 13-item measure of Williams and Anderson (1991), later modified by Somech \& Drach-Zahavy (2004). The questionnaire had two subscales first OCBI consisted of seven items that benefited particular individuals and second OCBO contained six items that benefited at organizational level. This study used five items to used to measure OCBO and OCBI each.

Multiple Regression Analysis was employed to check the below mentioned hypotheses.

H01: TransfLead style has a positive relationship with OCB.

H02: TransaLead style has a positive relationship with OCB.

H03: Laissez faire leadership (LaisfLead) style has a negative relationship with OCB.

\section{Data Analysis}

Table 1 shows the ANOVA results. Table shows $\mathrm{F}$ value is 67.261 and sig value is <.001 which is far below .05 percent hence this result suggests that the model hypothesis of "model has power to explain OCB" is rejected therefore the model has the ability to forecast OCB.

\begin{tabular}{ccccccc}
\multicolumn{1}{c}{} & \multicolumn{5}{c}{ Table 1 } \\
ANOVA \\
\hline & Model & SS & Df & MS & F & Sig. \\
\hline 1 & Regression & 30.853 & 3 & 10.284 & 67.261 & .000 \\
& Residual & 25.993 & 170 & .153 & & \\
& Total & 56.846 & 173 & & & \\
\hline
\end{tabular}

Coefficient of the regression model is shown in table 2. Coefficient table shows TransfLead has a standardized beta value of positive .367 which means that TransfLead predicts OCB and suggests that immediate supervisor who uses TransfLead Style can positively affect 36.7 percent of employees' exhibition of OCB. Similarly, TransfLead has standardized beta of .338 which suggest TransfLead Style positively affects OCB to an extent o 33.8 percent.

LaisfLead has beta value of -.305 which translates that LaisfLead style of immediate supervisor can 
negatively affect employees' OCB to an extent to 30.5 percent. For this model transformational leadership, $\mathrm{t}=6.616$, transformational leadership, $\mathrm{t}=6.089$ and laissez faire $\mathrm{t}=-5.267$ shows that these variables are significant predictor of OCB both positively and negatively where transformational $\mathrm{t}=$ 6.616 is lightly more in power than transactional $t=6.089$. Multicollinearity statistics shows the tolerance levels between independent variables is between .807 and .873, suggesting a strong tolerance level between independent variables and absence of Multicollinearity problem.

Similarly, Variance Inflation Factor (VLF) is between the range of 1.14 and 1.24 which also indicates that multicollinearity problem is not suspected between independent variables. Field (2005) suggested that tolerance level should be .10 and VIF value should be 10.0 or higher for the presence of multicollinearity.

Table 2

Coefficients of Regression Model

\begin{tabular}{ccccccc}
\hline & & \multicolumn{2}{c}{ UC } & SC & & Sig. \\
\hline 1 & Model & Std. Error & Beta & t & (Constant) \\
Transformational Leadership & 1.729 & .316 & & 5.475 & .000 \\
& .294 & .044 & .367 & 6.616 & .000 \\
& TransaLead & .406 & .067 & .338 & 6.089 & .000 \\
& Laissez-faire leadership & -.271 & .051 & -.305 & -5.267 & .000 \\
\hline
\end{tabular}

Stepwise regression analysis model shows that adjusted R square value for LaisfLead style is .298 which can be interpreted as when only one independent variable is used to calculate. The model LaisfLead style can explain 29.8 percent performance on OCB. Value of adjusted R square when used two independent variables LaisfLead style and TransfLead Style is .436 which can be translated that model has 43.6 percent power to interpret OCB when used two independent variables (transformational and laissez faire style). When used three independent variables value of adjusted $\mathrm{R}$ square is .535 meaning that using all three independent variables model has the power to explain 53.5 OCB. In light of the above analysis it can be inferred that when immediate supervisor exercises more TransfLead styles it has a positive effect on employees' OCB. Meaning if supervisor exhibits TransfLead Style employees are more likely to indulge in behaviors related to increased OCB. Hence the results support H01 that there is a positive relationship between TransfLead Style and OCB. Supporting the results of previous studies reviewed in this paper (Podsakoff et al., 1990; Nguni, Sleegers, \& Denessen, 2006; Nasra \& Heilbrunn, 2015).

These Results indicated the positive effect of TransaLead Style when explaining OCB. Results suggest that increase in immediate supervisor's TransaLead style has a positive impact on employee OCB. When supervisor increase their TransaLead Styles it may also reflect positively in employees' OCB. Therefore, supporting the assumption of hypothesis $\mathrm{H} 02$ and confirming the results of previous studies conducted in this respect. (Euwema et al., 2007; Asgari et al., 2008; Omar et al., 2009; Rodrigues \& Ferreira, 2015).

Lastly, LaisfLead style has the potential to negatively affect OCB. It can be translated as immediate supervisor who exhibit LaisfLead style will cause his subordinates to show less OCB hence suggesting H30 can be accepted that LaisfLead style negatively affect OCB and confirms findings of previous studies (Chaudhry \& Javed 2012; Zareen et al., 2015).

\subsection{Effect of Leadership Styles on Turnover Intention}

Following hypotheses were tested using Multiple Linear Regression. H04: there is no relationship between TransfLead and turnover intent 
H05: there is no relationship between TransaLead and turnover intent H06: there is no relationship between LaisfLead and turnover intent

Table 3 shows the ANOVA analysis of variance results. Values of interest in this table are $\mathrm{F}$ value and its correspondent $\mathrm{Sig}$ value. Table shows that $\mathrm{F}=132.396$ and sig value is $<0.001$ which is far below .05 percent hence this result suggests that the model hypothesis of "model has power to explain OCB" is rejected therefore it can be implied that model has the power to forecast employee turnover intention.

\begin{tabular}{ccccccc}
\multicolumn{7}{c}{ Table 3 } \\
\multicolumn{7}{c}{ ANNOVA } \\
\hline & Model & SS & df & MS & F & Sig. \\
\hline 1 & Regression & 42.176 & 3 & 14.059 & 132.396 & .000 \\
& Residual & 18.052 & 170 & .106 & \\
& Total & 60.228 & 173 & & \\
\hline
\end{tabular}

Table 4 shows the coefficient of the regression model. Coefficient table shows TransfLead has a standardized beta value of positive -0.198 which means that TransfLead predicts OCB and suggests that immediate supervisor who uses TransfLead style can negatively affect 19.8 percent of employees' turnover intention. Similarly, TransfLead has standardized beta value of -0.105 which suggest TransfLead style negatively effects turnover intention to an extent o 10.5 percent. LaisfLead has adjusted beta value of 0.703 which translates that LaisfLead style of immediate supervisor can negatively affect employees' turnover intention to an extent to 70.3 percent. For this model TransfLead, $\mathrm{t}=-4.414$, TransfLead, $\mathrm{t}=-2.334$ and laissez faire $\mathrm{t}=14.974$ shows that these variables are significant predictor of turnover intention both positively and negatively with laissez faire being the strongest and positively affecting turnover intention and can explain it to an extent of 70.3 percent.

Multicollinearity statistics shows the tolerance levels between independent variables between .801 and .873 suggesting a strong tolerance level between independent variables and absence of Multicollinearity problem. Similarly, variance inflation factor (VLF) is between the range of 1.249 and 1.146 which also indicate that Multicollinearity problem is not suspected between independent variables. Field (2005) suggested that tolerance level should be .10 and VIF value should be 10.0 or higher for the presence of Multicollinearity.

Table 4

Coefficients of Regression Model

\begin{tabular}{|c|c|c|c|c|c|c|}
\hline & \multirow{2}{*}{ Model } & \multicolumn{2}{|c|}{ UC } & \multicolumn{3}{|l|}{$\mathrm{SC}$} \\
\hline & & $\mathrm{B}$ & Std. Error & Beta & $\mathrm{T}$ & Sig. \\
\hline \multirow[t]{4}{*}{1} & (Constant) & 1.883 & .263 & & 7.159 & .000 \\
\hline & LaisfLead & .642 & .043 & .703 & 14.974 & .000 \\
\hline & TransaLead & -.130 & .056 & -.105 & -2.334 & .021 \\
\hline & TransfLead & -.164 & .037 & -.198 & -4.414 & .000 \\
\hline
\end{tabular}

Stepwise regression analysis model is shown in table 5. Adjusted R square value for LaisfLead style is .650 which can be interpreted as when only one independent variable was used to calculate the model LaisfLead style can alone explain 65.0 percent performance on employee turnover intention. Value of adjusted R square when used two independent variables LaisfLead style and TransfLead style is .687 which can be translated that model has 68.7 percent power to interpret turnover intention when used two independent variables (transformational and laissez faire style). When used three independent variables value of adjusted $\mathrm{R}$ square is .698 meaning that using all three independent variables model has the power to explain 69.8 percent of employee turnover intention. 
TransfLead Style has the potential to negatively affect turnover intention. It can be translated as immediate supervisor who exhibits LaisfLead style will cause his subordinates to show less turnover intention. Hence, suggesting $\mathrm{H}_{4} \mathrm{O}$ can be accepted that LaisfLead style negatively affect OCB as previous studies have shown (Martin \& Epitropaki, 2001).

Results above also indicate a negative effect of TransaLead Style when explaining turnover intention. Results suggest that increase in immediate supervisor's TransaLead Style has a negative impact on employee turnover intention. When supervisor increase their TransaLead Style it may also be reflected in employee less turnover intention. Therefore, supporting the assumption of hypothesis $\mathrm{H}_{0} 5$ and confirming the results of previous studies (Kim \& Jeong, 2009; Amankwaa \& Anku-Tsede, 2015)

Lastly in light of the above analysis it can be inferred that when immediate supervisor exercises LaisfLead style it has a positive effect on employees' turnover intention. It translates if supervisor exhibits LaisfLead style employees are likely to have an increased turnover intention. Hence the results support $\mathrm{H}_{0} 6$ that there is a positive relationship between LaisfLead style and employee turnover intention. Supporting the results of previous studies and help generalize the results (Skogstad et al.,2007; Chaudhry \& Javed 2012). Following hypothesis was also tested.

\section{$\mathrm{H}_{0} 7: \mathrm{OCB}$ and turnover intention are negatively related}

Table 5 presents coefficient table of the model. Standardized coefficients beta value is -0.681 suggesting that model OCB does explain turnover intention in a negative manger. Meaning increase in employee OCB can result in decreased employee turnover intention to an extent of 68.1 percent. $T$ value for OCB is -12.187 which suggest that OCB as independent has the power to predict employee turnover intention.

Table 5

Coefficients table of the model

\begin{tabular}{|c|c|c|c|c|c|c|}
\hline \multirow{2}{*}{\multicolumn{2}{|c|}{ Model }} & \multicolumn{2}{|c|}{ UC } & \multirow{3}{*}{$\begin{array}{c}\mathrm{SC} \\
\text { Beta } \\
\end{array}$} & \multirow{3}{*}{$\frac{\mathrm{T}}{23.680}$} & \multirow{3}{*}{$\begin{array}{c}\text { Sig. } \\
.000\end{array}$} \\
\hline & & $\mathrm{B}$ & Std. Error & & & \\
\hline 1 & (Constant) & 4.722 & .199 & & & \\
\hline & OCB Score & -.701 & .057 & -.681 & -12.187 & .000 \\
\hline
\end{tabular}

Results indicate a negative effect of OCB when explaining turnover intention. It also suggests that increase in employee citizenship behavior has a negative effect on employee turnover intention. Results reflect that employee turnover intention can be reduce with an increase in employee citizenship behavior. Therefore supporting the assumption of hypothesis $\mathrm{H} 07$ and confirming the results of previous studies (Khalid, 2005; Regts, \& Molleman 2013; Lau, McLean, Lien \& Hsu, 2016).

\section{Conclusion}

It was concluded in this study that supervisors who want their employee to show greater helping behavior, sportsmanship, organizational loyalty, organizational compliance, civic virtue and other behavior associated with organizational citizenship should exhibit more TransfLead style and TransaLead style while avoiding LaisfLead style and leaving them at their own. It was also concluded that leaving employee at their own and exhibiting more LaisfLead style would result in more employee burnout leading to employee turnover. Hence supervisors who try to avoid decision making and are unavailable when required are more likely to make their employees think about quitting.

\section{Discussion and Recommendations}

Future research can be directed on the need of question what else except leadership style and OCB causes employees of banks in Pakistan to think about voluntarily leaving the job. And more in-depth analysis can be focused on supervisors using other styles of leadership for example servant leaders, autocratic and e-leadership style as technology permits supervisors to remain in touch with their 
employees beyond conventional limitations. It can be a pertinent research question to investigate to what extent work pressure affects work life balance and its relationship with intention to quit. And to what extent it contributes to conflict or anti-OCB.

As previous research has shown notion of OCB can be different among individualistic and collective cultures (Farh et al., 2004). Hence Pakistan is an Asian country and have similar cultural values with other Asian countries for example collectivism it is necessary to investigate organizational citizenship as a concept in Pakistani context in order to further generalize the theory. Similar research should be carried out in other industries of Pakistan as it can help theory generalization. Unique cultural phenomenon like gender imbalance workforce and how gender plurality affect leadership style as there was not a single female supervisor observed in this study. Relationship between transformational and transactional leadership style and employee turnover intention needs to be investigated further because this study similar to some other studies suggest an insignificant relationship while it was shown in some studies that it has a direct and strong negative relation.

A relationship between personality types and leadership styles and how different personality types react to different leadership styles and its effect on employee work behaviors can be investigated. Since we know OCB is a voluntary work behavior which is not sanctioned by job requirements and is not rewarded in the formal reward system. Hence it can be investigated that how formal reward system is related to OCB.

\section{References}

Amankwaa, A., \& Anku-Tsede, O. (2015). Linking Transformational Leadership to Employee Turnover: The moderating role of alternative job opportunity. International Journal of Business Administration, 6(4), 19.

Aryee, S., Wyatt, T., \& Min M. A. (1990). Antecedents of organizational commitment and turnover intentions among professional accountants in different employment settings in singapore. The Journal of Social Psychology, 131(4) 545-556.

Asgari, A., Silong, A. D., Ahmad, A., \& Samah, B. A. (2008). The relationship between leader-member exchange, organizational inflexibility, perceived organizational support, interactional justice and organizational citizenship behavior. African Journal of Business Management, 2(8), 138.

Avolio, B. J., Bass, B. M., \& Zhu, F. W. W. (2004). Multifactor leadership questionnaire:manual and sampler set. Redwood City, CA: Mind Garden.

Baig, S. A., Iqbal, S., Abrar, M., Baig, I. A., Amjad, F., Zia-ur-Rehman, M., \& Awan, M. U. (2019). Impact of leadership styles on employees' performance with moderating role of positive psychological capital. Total Quality Management \& Business Excellence, 1-21.

Bass, B. M., \& Avolio, B. J. (2001). Developing transformational leadership: 1992 and beyond. Journal of European Industrial Training, 14, 21-27. doi:10.1108/ 03090599010135122

Campbell, J. W. (2017). Efficiency, incentives, and transformational leadership: Understanding collaboration preferences in the public sector. Public Performance \& Management Review, 41, 277-299. doi:10.1080/15309576.2017.1403332

Chaudhry, A. Q., \& Javed, H. (2012). Impact of transactional and laissez faire leadership style on motivation. International Journal of Business and Social Science, 3(7)

Cotton, J. L., \& Tuttle, J. M. (1986). Employee turnover: A meta-analysis and review with implications for research. Academy of management Review, 11(1), 55-70.

Curtis, G. J. (2018). Connecting influence tactics with full-range leadership styles. Leadership \& Organization Development Journal, 39, 2-13. doi:10.1108/LODJ-09-2016-0221

Euwema, M. C., Wendt, H., \& Van Emmerik, H. (2007). Leadership styles and group organizational citizenship behavior across cultures. Journal of Organizational Behavior, 28(8), 1035-1057.

Farh, J. L., Zhong, C. B., \& Organ, D. W. (2004). Organizational citizenship behavior in the People's Republic of China. Organization Science, 15(2), 241-253. 
George, J. M., \& Brief, A. P. (1992). Feeling good-doing good: A conceptual analysis of the mood at work-organizational spontaneity relationship. Psychological Bulletin, 112, 310-329

Göncü, A., Aycan, Z., \& Johnson, R. E. (2014). Effects of paternalistic and transformational leadership on follower outcomes. The International Journal of Management and Business, 5(1), 36-58.

Guimaraes, T., \& Igbaria, M. (1992). Determinants of turnover intentions: Comparing IC and IS personnel. Information Systems Research, 3(3), 273-303.

Hassan, S. (2013). The importance of role clarification in workgroups: Effects on perceived role clarity, work satisfaction, and turnover rates. Public Administration Review, 73(5), 716-725. doi:10.1111/puar.12100

Holtom, B., T. Mitchell and T. Lee. (2008). Turnover and retention research: a glance at the past, a closer review of the present, and a venture into the future. Academy of Management Annals, 291, 231-274.

Howell, J. M., \& Hall-Merenda, K. E. (1999). The ties that bind: The impact of leader-member exchange, transformational and transactional leadership, and distance on predicting follower performance. Journal of applied psychology, 84(5), 680.

Jensen, U. T., \& Bro, L. L. (2018). How transformational leadership supports intrinsic

motivation and public service motivation: The mediating role of basic need satisfaction. The American Review of Public Administration, 48(6), 535-549. doi:10.1177/0275074017699470

Jensen, U. T., Andersen, L. B., Bro, L. L., Bøllingtoft, A., Eriksen, T. L. M., Holten, A. L., ...

\& Westergård-Nielsen, N. (2019). Conceptualizing and measuring transformational and transactional leadership. Administration \& Society, 51(1), 3-33.

Judge, T. A., \& Piccolo, R. F. (2004). Transformational and transactional leadership: A meta-

analytic test of their relative validity. Journal of Applied Psychology, 89(5), 755-768. doi:10.1037/0021-9010.89.5.755

Karsh, B., Booske, B. C., \&Sainfort, F. (2005). Job and organizational determinants of

nursing home employee commitment, job satisfaction and intent to leave. Ergonomics, 48(10) 12601281.

Khalid, S. A. (2005). Organizational citizenship behavior, turnover intention and absenteeism of hotel employees. Unpublished doctorial dissertation). Universiti Utara Malaysia, Kedah, Malaysia

Kim, J. I., \& Jeong, H. S. (2009). The relationships of transformational leadership and transactional leadership on the hospital member's organizational commitment and turnover intention. Health Policy and Management, 19(2), 111-126

Kim, M., \& Beehr, T. A. (2017). Self-efficacy and psychological ownership mediate the effects of empowering leadership on both good and bad employee behaviors. Journal of Leadership \& Organizational Studies, 24(4), 466-478.

Kirkbride, P. (2006). Developing transformational leaders: The full range of leadership model in action. Industrial and Commercial Training, 38(1), 23-32.

Kiyak, A., Namazi, K., \&Kahana, E. (1997). Job commitment and turnover among women working in facilities serving older persons. Research on Aging, 19, 223-246.

Kleinman, C. (2004). The relationship between managerial leadership behaviors and staff nurse retention. Hospital topics, 82(4), 2-9.

Lau, P. Y. Y., McLean, G. N., Lien, B. Y. H., \& Hsu, Y. C. (2016). Self-rated and peer-rated organizational citizenship behavior, affective commitment, and intention to leave in a Malaysian context. Personnel Review, 45(3), 569-592.

Luthans, F., Avolio, B. J., Avey, J. B., \& Norman, S. M. (2007). Positive psychological capital: Measurement and relationship with performance and satisfaction. Personnel Psychology, 60 (3), 541-572.

Martin, R., \& Epitropaki, O. (2001). Role of organizational identification on implicit leadership theories (ILTs), transformational leadership and work attitudes. Group processes \& intergroup relations, 4(3), 247-262.

Mobley, W. H. (1977). Intermediate linkages in the relationship between job satisfaction and employee turnover. Journal of applied psychology, 62(2), 237. 
Nasra, M. A., \& Heilbrunn, S. (2015). Transformational leadership and organizational citizenship behavior in the Arab educational system in Israel: The impact of trust and job satisfaction. Educational Management Administration \& Leadership, 1741143214549975.

Nguni, S., Sleegers, P., \& Denessen, E. (2006). Transformational and transactional leadership effects on teachers' job satisfaction, organizational commitment, and organizational citizenship behavior in primary schools: The Tanzanian case. School effectiveness and school improvement, 17(2), 145 177.

Omar, Z., Zainal, A., Omar, F., \& Khairudin, R. (2009). The influence of leadership behaviour on organisational citizenship behaviour in self-managed work teams in Malaysia. SA Journal of Human Resource Management, 7(1), 11-pages.

Organ, D. W. (1988). Organizational citizenship behavior: The good soldier syndrome. USA: Lexington Books/D.C. Heath and Company.

Oshagbemi, T., \& Gill, R. (2004). Differences in leadership styles and behaviour across hierarchical levels in UK organizations. Leadership \& Organization Development Journal, 25(1), 93-106.

Ozaralli, N. (2003). Effects of transformational leadership on empowerment and team effectiveness. Leadership \& Organization Development Journal, 24(6), 335.

Pasha, O., Poister, T.H., Wright, B.E., \& Thomas, J.C. (2017). Transformational leadership and mission valence of employees: The varying effects by organizational level. Public Performance \& Management Review, 40, 722-740. doi:10.1080/15309576.2017.1335220

Podsakoff, N. P., Whiting, S. W., Podsakoff, P. M., \&Blume, B. D. (2009). Individual- and organizational-level consequences of organizational citizenship behavior: A meta-analysis. Journal of Applied Behavior, 94, 122-141.

Podsakoff, P. M., MacKenzie, S. B., Moorman, R. H., \& Fetter, R. (1990). Transformational leader behaviors and their effects on followers' trust in leader, satisfaction, and organizational citizenship behaviors. The leadership quarterly, 1(2), 107-142.

Popli, S., \& Rizvi, I. A. (2016). Drivers of employee engagement: The role of leadership style. Global Business Review, 17(4), 965-979. doi:10.1177/0972150916645701

Regts, G., \& Molleman, E. (2013). To leave or not to leave: When receiving interpersonal citizenship behavior influences an employee's turnover intention. Human relations, 66(2), 193-218.

Rodrigues, A. D. O., \& Ferreira, M. C. (2015). The impact of transactional and transformational leadership style on organizational citizenship behaviors. Psico-USF, 20(3), 493-504.

Roodt, G. (2004). Turnover intentions. Unpublished document: University of Johannesburg. Schnake, M. (1991). Organizational citizenship: A review, proposed model, and research agenda. Human Relations, 44, 735-759.

Teoman, S., \& Ulengin, F. (2018). The impact of management leadership on quality performance throughout a supply chain: An empirical study. Total Quality Management \& Business Excellence, 29(11-12), 1427-1451.

Teoman, S., \& Ulengin, F. (2018). The impact of management leadership on quality performance throughout a supply chain: An empirical study. Total Quality Management \& Business Excellence, 29(11-12), 1427-1451.

Williams, L. J., \& Anderson, S. E. (1991). Job satisfaction and organizational commitment as predictors of organizational citizenship and in-role behaviors. Journal of management, 17(3), 601-617.

Zareen, M., Razzaq, K., \& Mujtaba, B. G. (2015). Impact of transactional, transformational and laissezfaire leadership styles on motivation: A quantitative study of banking employees in Pakistan. Public Organization Review, 15(4), 531-549 